\title{
The Role of Information and Communication Industry (ICT) in the Reduction of Greenhouse Gas Emissions in Canada
}

\author{
Bentolhoda Abdollahbeigi, Farhang Salehi \\ Research Department, Rosha Consulting Group Ltd., Iran
}

\begin{tabular}{|c|c|}
\hline ARTICLE INFO & A B S T R A C T \\
\hline $\begin{array}{l}\text { Keywords: } \\
\text { ICT, } \\
\text { Greenhouse gas emissions, } \\
\text { Climate change, } \\
\text { Canada. } \\
\text { Kata Kunci: } \\
\text { TIK, } \\
\text { Emisi Gas Rumah Kaca, } \\
\text { Perubahan iklim, } \\
\text { Kanada }\end{array}$ & $\begin{array}{l}\text { According to the concerted efforts to reduce global greenhouse gas } \\
\text { emissions (GHGE), the Information and Communication Industry (ICT) } \\
\text { has received little attention as a significant contributor to GHG. ICT has } \\
\text { a very significant role to play in reducing greenhouse gas emissions in } \\
\text { Canada. While climate challenges increase, there is a growing need } \\
\text { to reduce Greenhouse gas emissions. The ICT sector has an important } \\
\text { role in enabling significant reductions in those emissions and costs. This } \\
\text { current study aims to examine the effects of GHGE on climate change } \\
\text { in Canada with a focus on the ICT sector. This paper will provide a } \\
\text { review of ICT definitions and Greenhouse gases and how GHGE can be } \\
\text { reduced. This paper presents an approach to investigating the impact } \\
\text { of information and communication technologies (ICTs) on Greenhouse } \\
\text { gases emission and its effect on climate change in Canada. }\end{array}$ \\
\hline
\end{tabular}

SARI PATI

Menurut tinjauan usaha bersama global dalam mengurangi emisi gas rumah kaca (EGRK), industri Teknologi, Informasi dan Komunikasi (TIK) kurang mendapat perhatian sebagai penyumbang EGRK yang signifikan. TIK memiliki peran yang sangat signifikan dalam mengurangi emisi gas rumah kaca di Kanada. Sementara tantangan iklim meningkat, ada kebutuhan yang semakin besar untuk mengurangi emisi gas rumah kaca. Sektor TIK memiliki peran penting dalam memungkinkan pengurangan yang signifikan dalam emisi dan biaya tersebut. Studi ini bertujuan untuk menguji efek EGRK pada perubahan iklim di Kanada dengan fokus pada sektor TIK. Makalah ini akan memberikan tinjauan tentang definisi TIK dan gas rumah kaca dan bagaimana EGRK dapat dikurangi. Makalah ini menyajikan pendekatan untuk menyelidiki dampak teknologi, informasi dan komunikasi (TIK) pada emisi gas rumah kaca dan pengaruhnya terhadap perubahan iklim di Kanada. 


\section{INTRODUCTION}

Information and communication technology devices and services have been an important part of our lives and have fundamentally changed the way we work, communicate, travel and play over the past few decades. In fact, while the human population has only doubled in the last 50 years, the global consumption of electronic devices has increased sixfold over the same period.

The main problem for the ICT industry is the exponential increase in energy consumption. With the development of ICT devices and services, our need for energy for production and electricity to power these devices is also increasing. The production of this much-needed energy for the construction and operation of all ICT devices on the market today is an important factor in the formation of carbon dioxide, a leading greenhouse gas (GHG), as well as other global heating pollutants. In recent years, there has been more awareness of climate change and its potentially devastating effects. There are more climate change initiatives than ever before with specific programs and strategies to reduce the negative effects of global warming on our environment. Information and Communication Technologies (ICT) can be used in cooperative measures to reduce greenhouse gas emissions and to reduce climate change. Information and communication technology can solve this and the problems that all countries face in terms of climate change, especially in Canada. Information and communication technology can be used to reduce the impact of other sectors on greenhouse gas emissions (GHG) and to help countries adapt to climate change.

A new International Telecommunication Union (ITU) states that following the Paris Agreement requires the Information and Communication Technology (ICT) industry to emit $45 \%$ of greenhouse gas emissions (GHG) from 2020 to 2030. Reduce greenhouse gas (GHG) production. Reducing greenhouse gas emissions to meet the UN Framework Convention on Climate Change (UNFCCC) targets the Paris Agreement to limit global warming to $1.5^{\circ} \mathrm{C}$ above pre-industrial levels. Canada strongly supports the Paris Agreement. This strategy of changing the situation in the middle of the century goes beyond 2030 to reduce the conversation about ways we can reduce emissions for a cleaner and more sustainable future by 2050 (Lotfi \& Ahmed, 2017).

Climate change is recognized as one of the defining challenges in Canada. The effects of hot weather and severe weather events in Canada are currently being felt and are expected to intensify and recur. Greenhouse gas emissions are projected to be nearly 30 percent higher than the target by 2030 . Governments across Canada see climate change as a defining challenge for the 21 st century. Provincial, territorial, and federal governments have pledged to take fundamental steps to combat climate change. Among other things, Canada has pledged to make international agreements to reduce greenhouse gas emissions by some levels by 2020 and 2030 (Environment and Climate Change Canada, 2020).

The federal government has also worked with provinces and territories to create a pan-Canadian framework for clean growth and climate change, with the goal of developing a national plan to reduce Canada's 2030 emissions reductions. Canadian governments have said that creating an effective response to climate change requires the cooperation of all levels of government across Canada. In most governments, there was limited coordination on climate change measures. At the federal, provincial, and territorial levels, there has been limited coordination on climate change measures in governments (Environment and Climate Change Canada, 2020). For example, the sectors that played a leading role in climate change often did not provide enough information, guidance, and training for the rest of the government. In many cases, limited coordination has led to temporary responses to climate change. Without effective coordination, governments may overlook important opportunities or challenges, or develop redundant and contradictory policies. 


\section{Problem Statement}

Canada's climate is changing; emissions in 2030 are expected to exceed the target by almost $30 \%$ Governments across Canada see climate change as a major 21 st century challenge. According to Natural Resources Canada, it is getting hotter and wetter, and extreme weather events are becoming more frequent. The impacts of climate change are felt across Canada and pose significant risks to Canadians and the economy. The federal, provincial and territorial governments recognize the threat posed by climate change. Most governments have committed to reducing greenhouse gas emissions, which are believed to be the biggest contributor to climate change. Therefore Climate change has been identified as one of the defining challenges in Canada. Hence this research will investigate the impact of information and communication technologies (ICT) on Greenhouse gases and its effect on climate change in Canada (Industry Canada Canadian ICT Statistical Overview 2019).

\section{Research Question}

What is the role of information and communication technologies (ICT), Greenhouse gases emission, and its effect on climate change in Canada?

\section{Resarch Objective}

To investigate the relationship between information and communication technologies (ICT), Greenhouse gases emission, and climate changes in Canada.

Research Hypothesis

There is a relationship between information and communication technologies (ICT), Greenhouse gases emission, and climate changes?

\section{METHODS}

In this research, both qualitative and quantitative analysis methods will be used. Definition of qualitative method is research that includes analysis and interoperation text and interviews to discover significant patterns descriptive of a specific phenomenon. Also, qualitative research is mainly exploratory research. It is used to gain an understanding of the underlying reasons, opinions and motivations. It provides an overview of the problem or helps develop ideas or hypotheses for potential quantitative research (Haradhan, 2018, Abdollahbeigi et al, 2017). This survey method will use data collection, populations are ICT sectors and the number of sample size will be 100 from ICT sectors among different states in Canada. Also, it will use the SPSS and Smart PLS to analyze the data which will be collected through interviews and observations. Using a semi-structured questionnaire is to make sure that it consisted of all the relevant questions on the specific information needed for the survey.

\section{Significant of Study}

This study is significant as it empirically investigates the ICTs on GHGE and its effect on climate change in Canada. A review of the literature also shows little evidence or no evidence of an empirical study on GHG emissions and climate change in Canada. Canadian governments have made commitments to reduce greenhouse gas emissions, which are thought to be the biggest contributors to climate change. Therefore Climate change is recognized as one of the defining challenges in Canada. Canada plans to achieve an economy-wide target to reduce its greenhouse gas emissions by $30 \%$ below 2005 levels by 2030. This target is ambitious but achievable. It represents a substantial reduction from Canada's business-as-usual emissions. CO2 emission poses a great danger to human health, both in the short and long term. It has been described by Opoku, (2018) as the most arduous and problematic of the greenhouse gas effects to manage. The bulk of $\mathrm{CO} 2$ emission is produced from ICT sectors. Findings from the study will help the government gain a better and practical understanding of the environment response to the activities of the ICT sector. Therefore, this study adds to several related works and also creates a platform that arouses some interest for further studies in this regard, serving as a source of reference for future studies in the area. 


\section{Scope of Study}

The study has focused on GHGE on climate change in ICT sector in Canada.

Information and communication technologies (ICT) can be used in cooperative action to reduce greenhouse gas emissions and in actions to mitigate climate change. ICTs can solve the problems that all countries face regarding climate change, especially in Canada. Also, this study aims to examine the effects of GHGE on climate change in Canada with a focus on the ICT sector. In addition, this research will try to identify how the information and communication technology (ICT) industry can help Canada reach the target of reducing greenhouse gas (GHG) emissions by 45 percent from 2020 to 2030 .

\section{LITERATURE REVIEW}

\section{A. ICT in Canada}

The Information and Communication Technology (ICT) industry is the backbone of the global digital economy and is one of the main drivers of knowledge-based productivity growth in the global economy. Semiconductors have become such a comprehensive feature of modern economics that they control the rhythm in which it runs Niebel, (2017). A distinctive feature of the ICT sector is the rapid rate of innovation and productivity growth that has occurred, not only in industries that produce hardware, software, microelectronics components, content, and services used in ICT applications but also in the sectors that benefit from the adoption and use of these technologies. Because no other industry or technology sector is more central to the development of globally competitive digital economies than the ICT sector, most countries aim to position their ICT industries to fuel postrecession growth (Maryska et al. 2012). Canada's technology sector is a major economic driver and is outperforming much of the rest of the country's economy. Canada's technology sector is a major economic driver and is outperforming much of the rest of the country's economy. "The Canadian ICT sector is highly trading dependent, importing US $\$ 35.7$ billion in goods and exporting US\$11.6 billion around the world in 2018". The United States is the second-largest supplier of ICT goods to Canada, at $\$ 6.6$ billion the top market for Canadian ICT exports with $\$ 7.8$ billion in 2018. "In 2018, total imports of ICT goods were led by the provinces of Ontario (US $\$ 26.6$ billion), British Columbia ( $\$ 3.8$ billion), Québec (US\$3.4 billion), and Alberta (US $\$ 1.1$ billion). The Canadian ICT market expects to continue growing through 2022"(Canadian ICT Sector Profile, Industry Canada 2020).

\section{Greenhouse gas emissions in Canada}

Geenhouse gas emissions from the information and communication industry (ICT) could grow by about 1 to 1.6 percent in 2007 and exceed 14 percent of level global GHG by 2040 (Lotfi and Ahmed, 2017). Greenhouse gases (GHG) are gases in the atmosphere that absorb and emit radiation in the thermal infrared range. They prevent heat from escaping from the atmosphere and make the earth warmer. The Kyoto Protocol, as the first major step towards a very realistic global emission reduction regime, invites all countries to reduce their greenhouse gas emissions. Therefore, many governments have taken steps to reduce energy consumption and greenhouse gas emissions. According to the Intergovernmental Panel on Climate Change, the International Science Evaluation Institute for Climate Change, Climate Change is largely due to the global burning of fossil fuels that emit greenhouse gases such as carbon dioxide into the atmosphere. Canada's greenhouse gas emissions, shown in Figure 1, increased in the 1990s and have remained relatively stable since 2000. Over the past 25 years, the international community has produced several UN agreements aimed at reducing global greenhouse gas emissions. These agreements include the Rio World Summit in 1992, the Kyoto Protocol 2005, the Copenhagen 2009 Agreement and the 2015 Paris Agreement.

Sources: "National Inventory Report 1990-2015: Greenhouse Gas Sources and Sinks in Canada", Environment and Climate Change Canada, 2019; Canada's Seventh National Communication on 


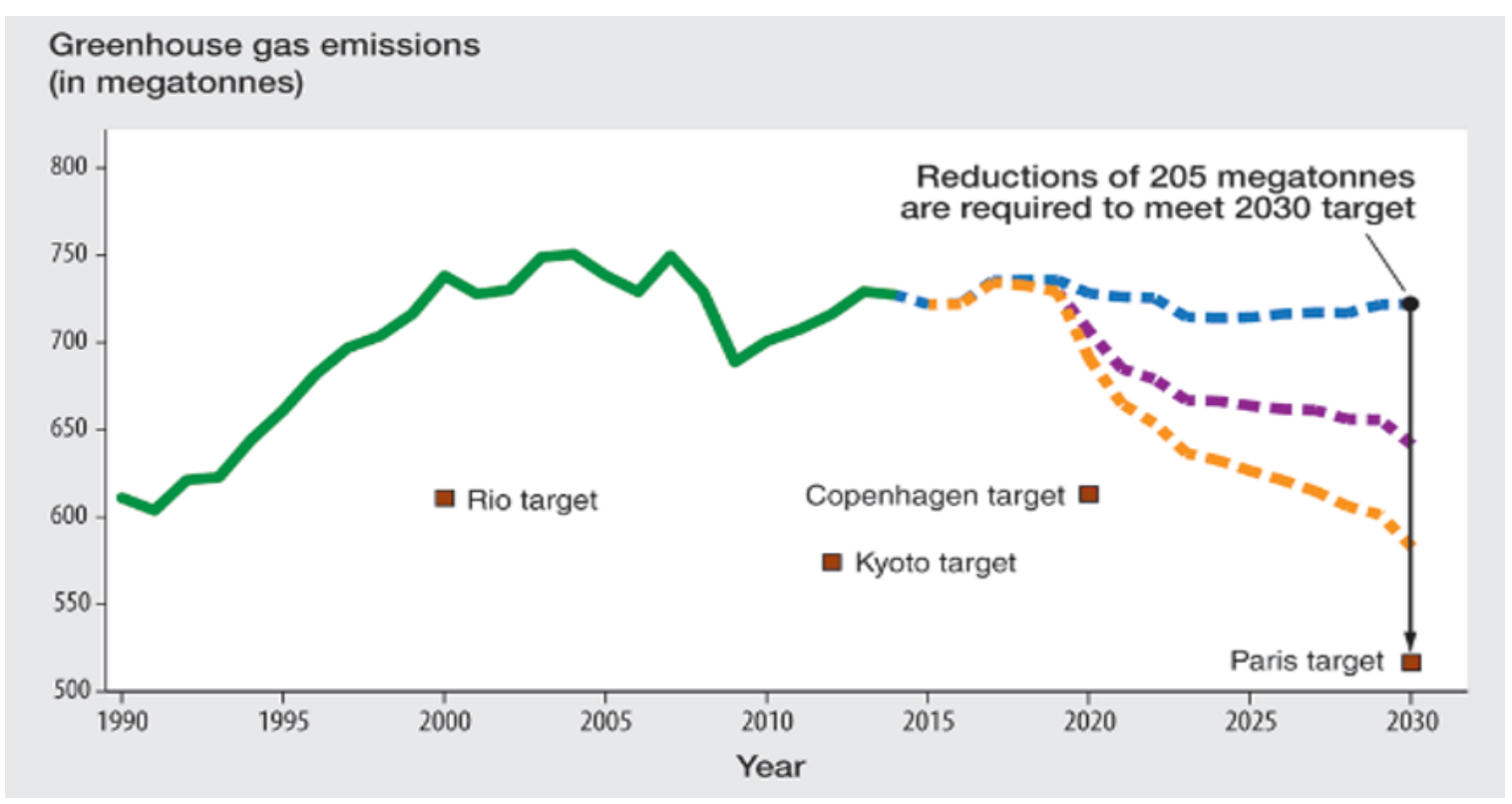

Climate Change and Third Biennial Report-Actions to meet commitments under the United Nations Framework Convention on Climate Change, Environment and Climate Change Canada, 2019.As a signatory to the agreements, Canada is committed to four separate goals to reduce greenhouse gas emissions. Canada failed to catch up with the first two targets - the 2000 Rio target and the 2008-2012 Kyoto targets. In addition, Canada's environment and climate change have predicted that current provincial and federal policies and regulations will mean that Canada will not be able to meet its 2020 Copenhagen goal (reducing greenhouse gas emissions to 17). Lower percentage than 2005). As part of their efforts to achieve Paris' goal in 2030, the federal, provincial, and territorial governments provided a pan-Canadian framework for clean growth and climate change. If all greenhouse gas emissions are implemented in a timely manner, Canada's environment and climate change estimate that Canada will need to reduce emissions by another 66 megatons to achieve its 2030 goal. Since 1990, some provinces have reduced their greenhouse gases. Greenhouse gas emissions are increasing, and others are steady or declining (Figure 2). For example, most Atlantic states, including Ontario and Quebec, now emit less greenhouse gases than in 1990, while Saskatchewan and Alberta both emit less than 1990 emissions. , Have increased by more than 50 percent.

Emissions from 1990 to 2015 are historical. Emissions from 2016 to 2030 are projections. Some governments disagree with the emission estimates produced by Environment and Climate Change Canada. The territorial emissions have not been included because not all estimates were available in 1990".

Sources: National Inventory Report 1990-2015: Greenhouse Gas Sources and Sinks in Canada, Environment and Climate Change Canada, 2019; Canada's Seventh National Communication on Climate Change and Third Biennial Report-Actions to meet commitments under the United Nations Framework Convention on Climate Change, Environment and Climate Change Canada, 2019

\section{Climate change in Canada}

Climate change is one of the most important environmental issues of our time. Climate change is caused by an increase in the concentration of 


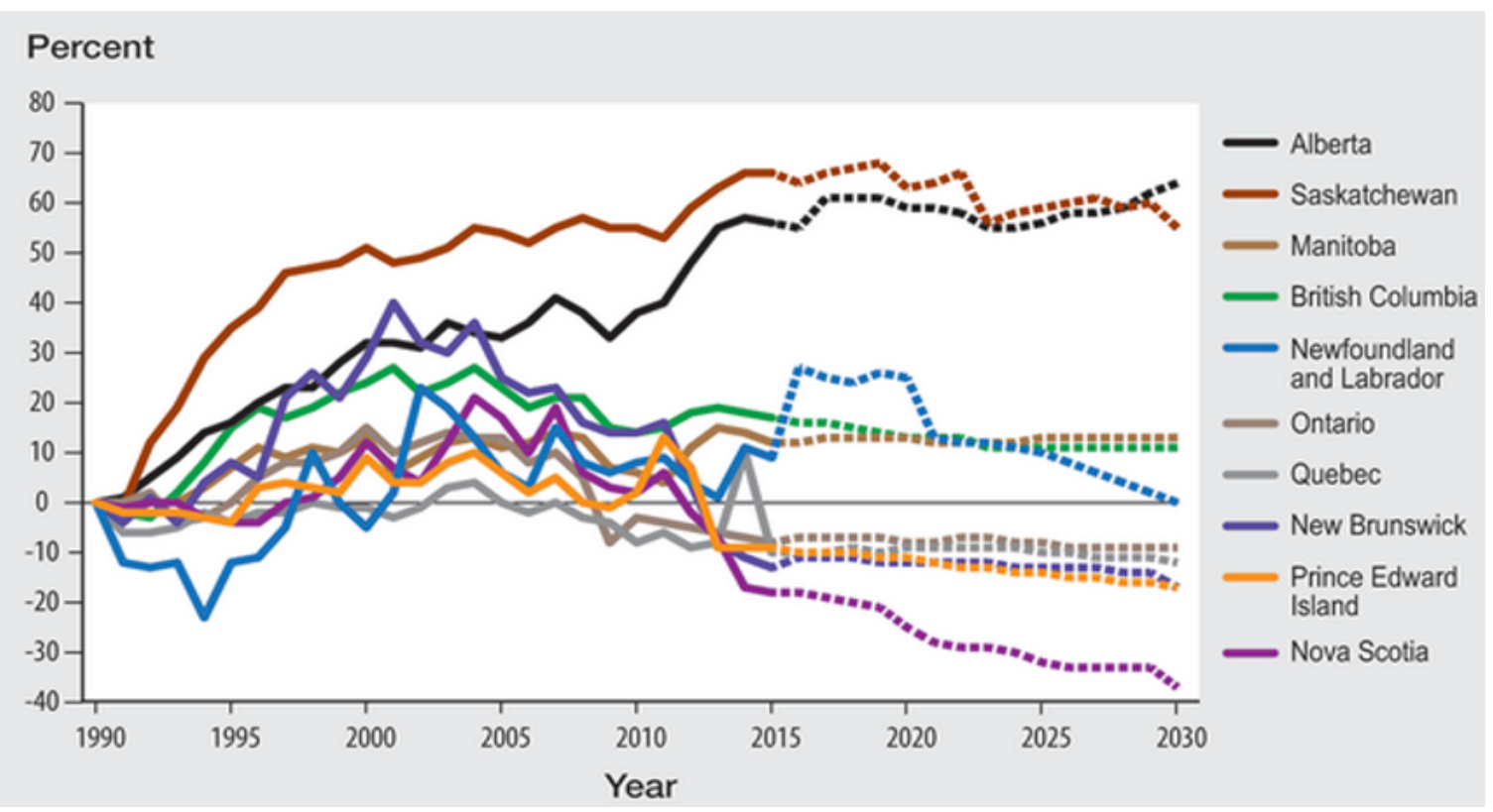

Figure 2. Provinces' actual and projected domestic greenhouse gas emissions relative to 1990 levels.

greenhouse gases (GHG) in the atmosphere. These increases are primarily due to human activities such as the use of fossil fuels or agriculture. Among the 17 sustainable development goals defined in the Agenda 2030, combating climate change is considered "one of the greatest challenges of our time and its adverse impacts undermine the ability of all countries to achieve sustainable development"(United Nations Framework Convention on Climate Change (UNFCCC), 2020). Combating climate change by reducing greenhouse gas (GHG) emissions is therefore a necessary (not sufficient) condition for sustainable development. Canada's climate is changing. Greenhouse gas emissions are projected to be nearly 30 percent higher than the target by 2030. Governments across Canada see climate change as a defining challenge for the 21 st century. According to Canada's natural resources, the country is getting warmer and wetter, and more severe weather events are occurring. The impact of climate change is felt across Canada and poses significant risks to Canadians and the economy (Environment and Climate Change Canada, 2020). Federal, provincial, and territorial governments recognize the threat posed by climate change. Most governments have made commitments to reduce greenhouse gas emissions, which is thought to be the biggest factor in climate change. Climate change is therefore recognized as one of the defining challenges in Canada. The effects of warmer climate and severe weather events in Canada are currently being felt and are expected to intensify and recur. Provincial, territorial, and federal governments have pledged to take fundamental steps to combat climate change. Among other things, Canada has pledged to reduce international agreements to reduce greenhouse gas emissions to certain levels by 2020 and 2030 . The federal government has also worked with provinces and territories to create a pan-Canadian framework for clean growth and climate change. It is intended to provide a national plan to achieve the goal of reducing Canada's 2030 emissions reduction. Canadian governments have said that creating an effective response to climate change requires the cooperation of all levels of government across Canada. In most governments, there was limited coordination on climate change measures. At the federal, provincial, and territorial levels, there has been limited coordination between governments on climate change. For example, the sectors that played a leading role in climate change often did 
not provide enough information, guidance, and training for the rest of the government. In many cases, limited coordination has led to temporary responses to climate change. Without effective coordination, governments may ignore important opportunities or challenges, or develop misguided and contradictory policies (Environment and Climate Change Canada, 2020).

\section{The information and communication technology (ICT), climate changes and greenhouse gases}

Research on the impact of ICT on activities that have implications on climate change began in the late 1980s with the pioneering work". There is evidence that the widespread use of information and communication technology is helping to reduce limited energy resources and increase greenhouse gas emissions (Sajda, 2019). It has been suggested that they are information and communication technology Sources that help increase CO2 emissions in terms of ICT machinery and equipment production, energy consumption and e-waste recycling (Higón. et al. 2017, Hilty et al., 2011). At the same time, information and communication technology can play a role in reducing greenhouse gases. Higón. et al. (2017) also found that information and communication technology can reduce $\mathrm{CO} 2$ emissions Worldwide with the development of smart cities, transportation systems, power grids, industrial processes, and energy-saving achievements. Their experimental results suggest that information and communication technology could help reduce $\mathrm{CO} 2$ emissions after reaching for developing information and communication technology. They found that at low levels of development, IT and communications investment increased $\mathrm{CO} 2$ emissions. $\mathrm{CO} 2$ emissions begin to decline after reaching the threshold of information and communication technology development. They also found that $\mathrm{CO} 2$ emissions increased with GDP per capita and the industry's share of valueadded. This ICT provides a useful insight into the elimination of environmental shocks caused by climate change. Technological productivity alone cannot sustain sustainability. Productivity comes from information and communication technology In fact, it may have the opposite effect. Despite the significant productivity of information and communication technology over the past decades. Hilty et al., (2011), Jayashree, et al., (2016), shows that there is no evidence of productivity strategies in terms of total energy consumption. It has only led to a stable situation. "Sustainable development is defined as the development that meets current needs without the ability of future generations to meet their needs". It seems that the role of information and communication technology for sustainable development in the fields of environmental economics, information systems/ green information technology and sustainable human-computer interaction Hilty et al., (2011) seems to be. Without effective restrictions, active information technology and information technology innovations, for example in cars, are progressing more slowly, instead, instead of stimulating additional activities (eg speeding, transportation attractiveness) instead. It replacing existing activities Hilty et al., (2011). There is a role for information and communication technology in information systems that help people in the organization to create a sustainable adaptation to climate change in their local communities. Processes adapted to climate change need to recover from the shock and change the environment, they said. How people deal with shock damage Abdollahbeigi \& Salehi, (2019). The process of adaptation requires good governance and assets such as human social and physical capital. Assets are more diverse in principle, the more stable and secure the living conditions, the stronger the population's ability to respond to impacts of climate change. "They add that in order to adapt to climate change, people need to adapt to the mobile social and physical resources they need to cope with climate change" Heeks \& Ospina, (2018). In adapting to climate change, the role of ICT is to provide systemic resilience to climate change. Skills and access to knowledge through ICTs have offered adaptation processes to the effects of climate change. "By sharing environmental observations and monitoring through ICT, new 
ways to assimilate information about changes in the natural environment can be shared through wider networks to bring about combined action" (Hilty et al., 2011, Melville, 2010, Abdollahbeigi \& Salehi, 2019).

\section{ICTs can impact on climate change in three main} ways:

- by driving down emissions in the ICT sector itself through the introduction of more efficient equipment and networks;

- by reducing emissions and enabling energy efficiency in other sectors through, for example, substituting for travel and replacing physical objects by electronic ones (dematerialization); and

- $\quad$ by helping both developed and developing countries adapt to the negative effects of climate change using ICT-based systems to monitor the weather and the environment worldwide" (Cook et al., 2016).

\section{MANAGERIAL IMPLICATIONS}

This article has provided a review of ICT definitions and Greenhouse gases and how GHGE can be reduced. Also, this research has approached investigating the impact of information and communication technologies (ICTs) on Greenhouse gases emission and effects on climate change in Canada. This research empirically investigated the ICTs on GHGE and its effect on climate change in Canada. A review of the literature also shows little evidence or no evidence of an empirical study on GHG emissions and climate change in Canada.
Canadian governments have made commitments to reduce greenhouse gas emissions, which are thought to be the biggest contributors to climate change. Therefore, Climate change is recognized as one of the defining challenges in Canada. Canada plans to achieve an economy-wide target to reduce its greenhouse gas emissions by $30 \%$ below 2005 levels by 2030. Findings from the study will help the government gain a better and practical understanding of the environment in response to the activities of the ICT sector. Yet, this article is expected to contribute to enrich microfinance discourses in which at the end, microfinance institutions and government can consider this issue.

\section{CONCLUSION}

We have conducted in this study what we believe to be a detailed explanation of ICT, GHGE, and how its effect on climate changes. "Information and communication technologies (ICT) can be used in cooperative action to reduce greenhouse gas emissions and in actions to mitigate climate change. ICTs can solve the problems that all countries face with regard to climate change, especially in Canada". This paper has highlighted how the information and communication technology (ICT) industry can help Canada reach the target of reducing greenhouse gas (GHG) emissions by 45 percent from 2020 to 2030 . The outcome will provide ICT companies knowledge in reducing GHG emissions. Also, the goal of limiting global warming to $1.5^{\circ} \mathrm{C}$ above pre-industrial levels which Canada strongly supports this plan. 
REFERENCES

Abdollahbeigi, B., \& Salehi, F. (2019). The impact of social media on purchasing intentions of green products. Asian Journal of Technology and Management Research (AJTMR.). Volume, 8(02).

Abdollahbeigi, B., Salehi, F., \& Jayashree, S.(2017). The effect of recruitment, selection and development on talent management in IKCO company in Iran. International Journal of Advanced Engineering and Management, 2(3): 69-77.

Cook, J., Oreskes, N., Doran, P. T., (2016). Anderegg, W. R. L., Verheggen, B., Maibach, E. W.,. .Rice, K. Consensus on consensus: A synthesis of consensus estimates on human-caused global warming. Environmental Research Letters. 11(4): 048002doi:10.1088/1748-9326/11/4/048002.

Environment and Climate Change Canada, (2020). Canadian Environmental Sustainability Indicators: Greenhouse gas emissions. Consulted on Month day, year. Available at: www.canada.ca/en/environment-climate-change/services/ environmental indicators/greenhouse-gas-emissions.html.

Haradhan Kumar Mohajan (2018). Qualitative Research Methodology in Social Sciences and Related Subjects. Journal of Economic Development, Environment and People, Vol-7, Issue 01, pp. 23-48.

Heeks, R., \& Ospina, (2018). A. Linking ICTs and climate change adaptation: A conceptual framework for eResilience and eAdaptation. Manchester: Centre for Development Informatics.

Higón, D. A., Gholami, R., \& Shirazi, F. (2017), ICT and environmental sustainability: A global perspective. Telematics and Informatics, 34(4), 85-95.

Hilty, L., Lohmann, W., \& Huang, E. (2011). Sustainability and ICT—an overview of the field. Politeia, 27(104), 13-28.

Jayashree, S., Malarvizhi, C. A., Abdollahbeigi, B., \& Salehi, F. (2016). The Efficiency of e-Commerce and Social Media on Product Innovation and Business Success. Advanced Science Letters, 22(5-6), 1411-1414.

Keeble, B. R. (1988). The Brundtland report: 'Our common future'. Medicine and War, 4(1), 17-25.

Lotfi B, Ahmed E (2017). Assessing ICT global emissions footprint: Trends to 2040 \& recommendations. Journal of Cleaner Production, Volume 177, Pages 448-463 doi: 10.1016/j.jclepro.12.239.

Maryska, M., Novotny, O. et al. (2012). Lidské zdroje v ICT - nabídka a poptávka v $\square$ eské republice. 1. vyd. Praha. Professional Publishing. ISBN 978-80-7431-082-9.

Melville, N. P. (2010). Information systems innovation for environmental sustainability. MIS Quarterly, 34(1), 1-21.

Niebel, T. (2017). ICT and economic growth - Comparing developing, emerging and developed countries, World Development. 104. 197-211.

Opoku Mensah S. (2018). Assessing The Livelihood Gains Of Forest Host Communities And The Management Of The Bobiri Forest Reserve (BFR) In Ghana.

Ratheeswari, K. (2018). Information Communication Technology in Education. Journal of Applied and Advanced Research, 3(Suppl. 1) S45?S47. v3S1.169.

Sajda Q. (2019). Climate change adaptation for sustainable development: the information and communication technology (ICT) paradox. Information Technology for Development. 25:4, 625-629, DOI: 10.1080/02681102.2019.1680164.

Salehi, F., Abdollahbeigi, B., \& Sajjady, S. (2021). Factors Affecting the Trust in the Online Shopping and E-commerce Success of Companies. Asian Research Journal of Current Science, 1-5.

Salehi, F., Abdollahbeigi, B., \& Sajjady, S. (2021). Impact of Effective IT Governance on Organizational Performance and Economic Growth in Canada. Asian Journal of Economics, Finance and Management, 3(2), 14-19. Retrieved from https:// www.globalpresshub.com/index.php/AJEFM/article/view/945.

United Nations Framework Convention on Climate Change (UNFCCC), (2020). Adoption of the Paris Agreement: Proposal by the President: Draft decision -/CP.21. Paris. 